\title{
A coluna política de Adalgisa Nery no Jornal Última Hora e a crise pré-1964 no Brasil.*
}

\author{
The political column by Adalgisa Nery in the newspaper Última Hora \\ and the pre-1964 crisis in Brazil.
}

\section{Isabela Candeloro Campoi ${ }^{* *}$}

\section{RESUMO}

Entre o fim da Era Vargas e o golpe civil-militar de abril de 1964, a escritora Adalgisa Nery publicou diariamente uma coluna política no jornal "Última Hora." Seu trabalho no jornalismo Ihe rendeu uma cadeira como deputada estadual da Guanabara, estado criado após a transferência da capital federal para Brasília em 1960. Herdeira da tradição política de Getúlio Vargas, Adalgisa Nery tinha um estilo que Ihe era característico, valendo-se de metáforas, ironia e certa dose de agressividade, sustentando uma posição fortemente nacionalista. A proposta deste artigo é discutir a polarização política refletida na imprensa brasileira às vésperas do golpe civil-militar de 1964 por meio da análise dos artigos da coluna "Retrato sem retoque" assinada por Adalgisa Nery.

Palavras-chave: Imprensa. Jornalismo. Golpe civil-militar. Nacionalismo. Guerra Fria.

\section{ABSTRACT}

Between the end of Vargas' Era and the civil-military coup of April 1964, the writer Adalgisa Nery published a daily political column in the newspaper Última Hora. With her work in the journalism Adal gisa was elected deputy of Guanabara, a new State created after the change of Brazilian's federal capital to Brasília, in 1960. Adalgisa Nery was heir to the Vargas political tradition and had a very special style, using metaphors, irony and a certain amount of aggressiveness, sustaining a strongly nationalist position. The purpose of this article is to discuss the political polarization reflected in the Brazilian press on the eve of the military coup of 1964 by analyzing the articles in the column named Retrato sem retoque by Adalgisa Nery.

Keyword: Press. Press. Civil-military coup. Nationalism. Cold War.

\footnotetext{
* Este artigo é parte da tese de doutorado defendida junto o Programa de Pós-Graduação em História Social da Universidade Federal Fluminense, UFF em 2008 e teve financiamento da CAPES (Coordenação de Aperfeiçoamento de Pessoal de Nível Superior)

** Professora Adjunta no Colegiado de História da Universidade Estadual do Paraná, UNESPAR, campus de Paranavaí e do Programa de Pós-Graduação em Ensino, PPIFOR, na mesma instituição.
} 
As dimensões a respeito das relações entre história e imprensa têm sido ampliadas e recebido especial atenção da historiografia. A imprensa é guardadora da memória de um tempo e muitas vezes pode despertar como agente histórico, crucial num contexto de acirramento de posições e de disputa política. Em meados da década de 1950 a imprensa era o meio, por excelência, de acesso ao mundo e aos acontecimentos, e exerceu papel fundamental na elaboração da crise política que culminou com o suicídio do presidente Vargas.

Os jornais e a mídia impressa, de uma maneira geral, detinham expressivo poder na formação da opinião pública num período em que a televisão dava os seus primeiros passos. Nos anos 1950, os jornais tinham importante tom político e ideológico que caracterizava a identidade dos diários, assim como a segmentação do seu público leitor. Como formadora de opinião pública, portanto, veículo indispensável, a imprensa sustentava posicionamentos políticos mais nítidos e era consagrada entre os articuladores políticos da capital da República.

Ao recuperarmos a relação existente entre política e imprensa nesse período, o panorama é bastante interessante. $O$ "Tribuna da Imprensa" foi fundado por Carlos Lacerda em 1949. O "Jornal do Comércio" era de San Tiago Dantas. Em 1950, Chagas Freitas assumiu a direção de "A Notícia", jornal comprado em sociedade com Ademar de Barros com fins claramente eleitorais. ${ }^{1}$ O jornal "Última Hora" nasceu com o intuito de dar sustentação ao segundo governo Vargas e cumpriu este papel mesmo depois da sua morte: o jornal de Wainer foi verdadeira trincheira do nacionalismo na imprensa.

Da mesma forma, os anos 1950 trouxeram mudanças significativas quanto à ampliação do parque gráfico e às estratégias voltadas à cultura de massa: inovações na diagramação e apresentação das matérias, diversificação temática, certa objetividade jornalística, novas técnicas de produção e administração. Segundo Marieta de Moraes Ferreira, "o jornal Última Hora é um exemplo desse quadro de mudanças que já vinha se delineando desde o início da década. [...] a Última Hora revolucionou a imprensa, introduzindo uma série de novas técnicas de comunicação de massa." (FERREIRA, 1996, p.143-144).

O responsável pela criação do jornal vespertino "Última Hora", Samuel Wainer, trabalhava como repórter do "O jornal" de propriedade de Assis Chateaubriand. Em 1949, escalado para fazer uma reportagem sobre o trigo no sul do país, Wainer conseguiu uma entrevista com Vargas, noticiando seu retorno como líder de massas. Após o carnaval

${ }^{1}$ Carlos Lacerda elegeu-se deputado federal em 1955 e governador da Guanabara em 1960 pela UDN. San Tiago Dantas foi deputado federal por Minas Gerais em 1959, passou pelos ministérios das Relações Exteriores entre 1961 e 1962 e da Fazenda em 1963. Chagas Freitas foi deputado federal entre 1955 e 1971, além de último governador da Guanabara. Ademar de Barros foi interventor (1938-1941) e governador (1947-1951/1963-1966) de São Paulo e candidato à presidência da República por duas vezes, em 1955 e 1960. Ver: Abreu (2000). 
daquele ano, diversos veículos dos "Diários Associados" anunciavam a volta do ex-ditador: a notícia, então inédita, "caiu como uma bomba" nos meios políticos e Chateaubriand, convenientemente, soube tirar proveito da situação. Wainer afirma que, em média, a vendagem de "O jornal" era de 9.000 exemplares. Porém, tal edição vendeu $\mathbf{1 8 0 . 0 0 0}$ números. (WAINER, 1988, p.25)

Desde então, por conta da repercussão positiva da reportagem e de outras que se seguiram tratando da volta de Getúlio Vargas como candidato à presidência da República em 1950, Wainer iniciou estreita relação com o ex-ditador, que passou a chamá-lo sob a alcunha de 'Profeta'. O jornal "Última Hora" surgia em 12 de junho de 1951, revelando seu caráter nitidamente getulista. Foram 20 anos sob direção de Samuel Wainer. Após seis meses de existência tornou-se líder de circulação no Rio de Janeiro e paulatinamente inaugurou sucursais em diversos estados do país.

O sucesso editorial do jornal de Wainer, um outsider entre os donos de jornal, provocou a ira dos poderosos da imprensa brasileira. Procurando atingir Wainer e indiretamente o presidente Vargas, o "Última Hora" foi acusado de favoritismo nos empréstimos concedidos pelo Banco do Brasil, incitando um caso atípico na imprensa brasileira: a instalação de uma Comissão Parlamentar de Inquérito - CPI.

Em uma outra frente de acusação, Wainer era suspeito de não ter nascido no Brasil. Segundo a Constituição de 1946, estrangeiros não podiam ser donos de jornal. Num jogo de investigação e intrigas, Assis Chateaubriand e Carlos Lacerda publicaram, por cerca de três anos (1953-1956), notícias envolvendo Wainer e suas empresas de comunicação. A CPI teve fim em novembro de 1953 constatando irregularidades; por desacato ao Congresso, Wainer chegou a ser preso. O objetivo de seus opositores políticos era encontrar brechas para promover o impeachment do presidente Vargas.

Dado seu estreito relacionamento com o Catete, a delicada posição de Samuel Wainer atingia Getúlio Vargas, contribuindo para o seu enfraquecimento político junto às elites. $O$ atentado contra o então jornalista Carlos Lacerda foi ponto crucial da intriga que resultou na morte de Getúlio Vargas em agosto de 1954. A imprensa comportou-se como personagem decisiva na crise que culminou no suicídio do presidente. Os reflexos dessa situação podem ser identificados na violenta reação popular manifestada contra as sedes de periódicos e estações de rádio que se opunham à Vargas no Rio de Janeiro. (FERREIRA, 2005, p.179).

Com a bombástica manchete publicada à pedido de Getúlio: "Só morto sairei do Catete", o único jornal que circulou no 24 de agosto foi o "Última Hora." Os acontecimentos da década seguinte eriam cruciais: em abril de 1964 esse mesmo jornal teria sua sede atacada e incendiada. Que rumos políticos a imprensa percorreu nesse período de democracia então inédita no Brasil? 


\section{Breve trajetória política de Adalgisa Nery}

Nos cerca de 10 anos que separam o desaparecimento de Vargas e o golpe civil-militar, Adalgisa Nery manteve uma coluna diária no jornal "Última Hora", ou seja, entre novembro de 1954 e abril de 1964, a coluna "Retrato sem retoque" era comumente publicada na segunda página do jornal, periódico onde a escritora encontrou espaço propício para defender suas idéias.

Os primeiros artigos de Adalgisa Nery foram publicados no segundo caderno, junto de charges e notícias de entretenimento, destoando dos assuntos trata dos na coluna. Propondo escrever sobre política e economia, a publicação de seus textos no caderno cultural motivou a reclamação de Adalgisa Nery, que em um telefonema ao diretor e dono do jornal, solicitou: "Eu não fico em caderno de mulher [...] quero o caderno dos homens, quero o primeiro caderno." (WAINER, 1988, p. 247).

Neste ponto, valem algumas observações. As mulheres atuavam na grande imprensa dos anos 1950 tratando de assuntos freqüentemente ligados ao âmbito doméstico. De um modo geral, o conteúdo das colunas e cadernos femininos publicados nos jornais abrangia temáticas que vinculavam as mulheres ao universo doméstico, confirmando o discurso dominante, os papéis a que foram destinadas.

A reação de Adalgisa Nery pode ser compreendida se recuperarmos as temáticas tratadas pelas mulheres na imprensa daquele período: moda e beleza, culinária e decoração, família e educação dos filhos, relacionamentos afetivos, ou então publicando contos e crônicas romanescas. (BUITONI, 1981, p.85). Caracterizando o primeiro caderno como um espaço jornalístico dos homens e verificando o tipo de imprensa que as mulheres faziam naquele momento, a escritora assumiu o discurso dominante e reivindicou o espaço reservado aos homens: a eles eram destinados os assuntos sérios como política e economia; ao propor tratar desses temas, Adalgisa Nery efetivou a exigência, tanto que tal discurso foi assimilado por ela e pelo jornal.

A escritora era velha conhecida de Samuel Wainer, já que, em meados de 1938, publicou textos literários na revista "Diretrizes: política, economia, cultura." A publicação foi idealizada e dirigida por Samuel Wainer e tratava de assuntos contemporâneos polêmicos como o nazi-fascismo e a política internacional, valendo-se de charges, material fotográfico e colaboração de escritores estrangeiros. Em um período bastante delicado da política nacional, Wainer mantinha colaboradores ou como conselho diretor da revista figuras como Astrogildo Pereira, um dos fundadores do Partido Comunista Brasileiro - PCB, Graciliano Ramos, também ligado ao Partido Comunista, considerado opositor histórico do Estado 
Novo, além de Carlos Lacerda - então vinculado ao PCB - Rubem Braga, Jorge Amado e Raquel de Queirós.

Em plena ditadura do Estado Novo, a revista e muitos de seus colaboradores, tais como Carlos Drummond de Andrade, José Lins do Rego, Érico Veríssimo, Álvaro Moreira, Jorge de Lima, Murilo Mendes, Rubens Braga, Aurélio Buarque de Holanda entre outros, assim como Adalgisa Nery, foram fichados pela polícia política do governo como comunistas. ${ }^{2}$

Adalgisa Nery era viúva do pintor Ismael Nery, morto em 1934, e foi a partir desta relação que a escritora inseriu-se nesta rede de intelectuais cariocas. Nos anos 1930-1940 a livraria José Olympio, as confeitarias Colombo e Cavé, eram espaços importantes de sociabilidade e de encontro da intelectualidade carioca. Foi quando Adalgisa Nery conheceu Lourival Fontes, diretor-geral do Departamento de Imprensa e Propaganda - DIP, órgão de censura e propaganda ideológica do Estado Novo, com quem se casou em maio de 1940.

Esse segundo enlace proporcionou à Adalgisa Nery vínculos com as instâncias governamentais, na medida em que passou a freqüentar as entranhas do poder, promovendo festas e reuniões sociais, tratada nas colunas sociais como a Senhora Lourival Fontes.

Fichada como comunista pela polícia política desse governo, Adalgisa casou-se com um explícito simpatizante do fascismo: o itinerário de nossos intelectuais produz fenômenos curiosos, que numa análise de gênero, pode explicitar a força de significados que a princípio estão expostos no campo do privado, mas que o transborda rumo ao campo da rede social. Wainer, editor de dono de "Diretrizes", afirmou:

Adalgisa, uma linda mulher, escrevia textos muito interessantes, não era preciso ser indulgente para publicá-los. Mas o fato de ser casada com Lourival Fontes, naturalmente valorizava sua presença na redação de Diretrizes e oferecia à revista algum tipo de segurança. (WAINER, 1988, p.51).

Assim, Adalgisa funcionava como uma espécie de escudo protetor à revista "Diretrizes" que sob essa égide, preservava seus colaboradores. Com a entrada do Brasil na II Guerra Mundial em 1942, Lourival, conhecido simpatizante do Eixo, foi retirado de cena depois de anos colaborando com o regime varguista. Com a ascensão democrática de Vargas o casal

\footnotetext{
${ }^{2}$ Documento do setor Comunismo da Divisão de Polícia Política e Social - DPS, depositado no Arquivo Público do Estado do Rio de Janeiro, Pasta: 4-D, carta de 01/11/1939.
} 
volta ao Brasil depois de ter passado pelo Canadá, Inglaterra, EUA e México: Lourival Fontes tornou-se chefe do gabinete civil da presidência.

O casamento teve fim tempestivo em 1953. Acometida de forte depressão, Adalgisa chegou a ser hospitalizada e em fins de 1954 deu início à trajetória como articulista política do jornal "Última Hora", atividade que a elegeu por dois mandatos como deputada estadual da Guanabara, primeiro como constituinte pelo Partido Socialista Brasileiro - PSB; em 1963 filiou-se ao Partido Trabalhista Brasileiro - PTB e por fim, com a imposição do bipartidarismo transferiu-se para o Movimento Democrático Brasileiro - MDB. Após a morte de Vargas o jornal "Última Hora" tornou-se verdadeira trincheira do nacionalismo: jornal e jornalista identificavam-se como herdeiros políticos de Getúlio Vargas.

Traçada esta breve trajetória da escritora, imprescindível para a compreensão de seu posicionamento político em seu trabalho no jornalismo, é preciso considerar o conturbado contexto nacional após o suicídio do presidente Vargas. O grau de aproximação de Adalgisa e Getúlio Vargas pode ser observado na capa da "Revista da Semana" de 23 de outubro de 1954, documento localizado no Acervo "Adalgisa Nery", depositado na Fundação Casa de Rui Barbosa no Rio de Janeiro.

Figura 1- Testemunho de Adalgisa Nery

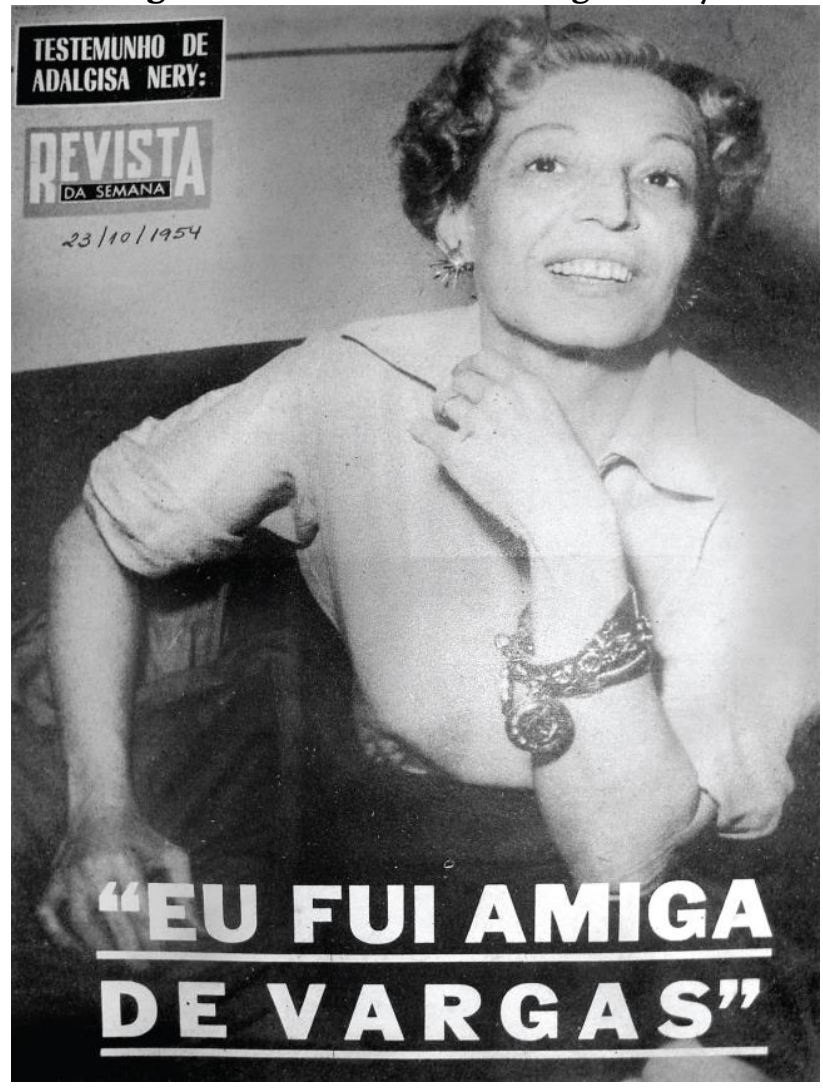

Fonte: Revista da Semana, 23 out. 1954. 
Com a chamada "Eu fui amiga de Vargas." Ela relatou a admiração ao "homem profundamente bom, de trato simples e cordial." Ainda sob os ares da grande comoção nacional, explicitou a aproximação: "Foi um amigo inesquecível e atencioso nas minhas horas confusas, e sempre tive da sua parte uma palavra de acolhimento e simpatia." Adalgisa expressou sua opinião sobre o governo de Café Filho e a sua "investidura à Presidência da República da forma dolorosa e apreensiva como se apresentou." Sobre os acontecimentos de agosto, afirmou:

Em nenhuma época da minha vida conservei distância ou indiferença aos processos políticos e sociais do mundo e jamais poderia negar a minha participação ao que se passava no meu país naqueles inesquecíveis dias. O Brasil esteve e está acima do meu universo emocional. Estou certa de que o fato da mudança de homens não o afasta dos seus rumos, das suas diretrizes, das suas dependências e conveniências. (Revista da Semana, 23 out. 1954, p.49).

Com comentários otimistas sobre a economia do país, citando os pontos que deveriam orientar as ações do novo presidente, Adalgisa mostrou-se bastante segura em suas opiniões. Perguntada sobre a chamada política de austeridade apregoada pelo novo governo ela respondeu e analisou a conjuntura em que "até sangue entrou na composição dos acontecimentos":

A austeridade, no sentido moral de bons costumes, é um dever e não uma possibilidade. Não vamos culpar o doutor Getúlio Vargas pelo desdobramento violento da autoridade mal aplicada. Todos temos culpa e todos participamos para os acontecimentos. Os amigos porque não souberam ajudá-lo com mais eficiência, e os inimigos porque o atacaram pessoalmente sem reconhecerem suas intenções e as suas boas realizações. A austeridade imprescindível ao governo foi afastada quando governadores, ministros, industriais, militares, políticos, enfim, de categoria e de responsabilidade, saíram da respeitabilidade de suas funções para trocarem favores e simpatias com pessoas que sabiam sem função legal e idoneidade moral para uma aproximação honesta. (Revista da Semana, 23 out. 1954, p.49). 
A partir de sua versão dos acontecimentos, ela referiu-se à necessidade de que "sejam devolvidas às palavras, às responsabilidades e aos juramentos de honra, as suas verdadeiras almas." E finaliza: "Necessitamos de seriedade e, acima de tudo, parar para pensar." (Revista da Semana, 23 out. 1954, p.49).

Eis aí um esboço da colunista política que tão logo Adalgisa Nery se tornaria. Foi nesse cenário político que uma nova face sua desabrochou. Detentora de uma imagem pública já estabelecida, a experiência com o governo Vargas dava a Adalgisa Nery condições de adentrar num campo de ação inédito. Como um mecanismo de inserção, Adalgisa esteve condicionada a uma circunstância política favorável que marcaria seu destino. O suicídio de Vargas funcionou como um marcador para transformações profundas em sua trajetória individual, afinal, foi o trabalho como colunista que lhe trouxe os votos que a elegeram anos depois.

\section{A atuação de Adalgisa Nery no Jornal "Última Hora"}

Os artigos de Adalgisa Nery nas páginas do jornal "Última Hora" eram carregados de metáforas, expressões irônicas e linguagem figurativa. As duras críticas eram disparadas aos representantes políticos, às instituições financeiras e aos setores da economia acusados de entreguistas. O discurso nacionalista foi a principal marca da coluna "Retrato sem Retoque" e também por conta disto ela cultivou muitos inimigos.

Tal aspecto ficou claro já no seu artigo de estreia. Com o título "A incontinência do embaixador" Adalgisa comentou sobre uma entrevista "não muito amiga nem muito ponderada" dada pelo embaixador Kemper de férias em Boston. "Na sua incontinência americana de julgar e preponderar" Kemper tratou sobre a exportação brasileira de café e incomodou-se: "li e desgostei profundamente porque ainda possuo traços de dignidade e amor próprio de brasileira." (Última Hora, 04 nov. 1954) ${ }^{3}$

De fato o tom nacionalista foi a principal marca da coluna "Retrato sem retoque." Adalgisa tinha vínculos com o Instituto Superior de Estudos Brasileiros - ISEB, fundado em 1955 como um órgão do Ministério da Educação e Cultura. Através de cursos, conferências e publicações:

${ }^{3}$ O acervo do jornal “Última Hora” foi pesquisado em microfilmes depositados na Biblioteca Nacional do Rio de Janeiro. 
O ISEB foi um dos núcleos mais importantes de elaboração da ideologia "nacional-desenvolvimentista" que impregnou todo o sistema político brasileiro desde a morte de Getúlio Vargas, em 1954, até a queda de João Goulart, em 1964. (ABREU, 2000).

Os intelectuais ligados ao ISEB sustentavam posições pessoais heterogêneas, e a publicação "O nacionalismo na atualidade brasileira" de Hélio Jaguaribe, em 1958, funcionou como um 'divisor de águas' no grupo. Sua opinião favorável à exploração do setor petroquímico por empresas privadas, além de considerar vantajosos os investimentos estrangeiros no país, gerou discórdias quanto à posição nacionalista do instituto, provocando o desligamento de Jaguaribe do grupo.

Num curto primeiro momento, o nacionalismo isebiano estivera ligado aos adeptos da "via tecnocrática de desenvolvimento", quando figuravam, por exemplo, Roberto Campos e Augusto Frederico Schmidt, assim como Gilberto Freyre e Sérgio Buarque de Hollanda. ${ }^{4}$ (TOLEDO, 1977) Muitos haviam tido vínculos com o Estado Novo, muitos eram parte da inteligência da ditadura Vargas: pensavam o Brasil, projetavam um país. Adalgisa Nery era a relações públicas desse regime, estabelecendo vínculos entre o poder instituído e a intelectualidade da época.

Focando a produção dos principais intelectuais do ISEB, Caio Navarro de Toledo (1977, p.186) identifica três fases características do instituto. A partir das publicações e conferências de Roland Corbusier, Guerreiro Ramos, Cândido Mendes e Nelson Werneck Sodré, principalmente, o autor dá a conhecer os preceitos ideológicos do grupo, onde se debatia conceitos como "consciência das massas" e "subdesenvolvimento", por exemplo. Eles procuravam decifrar o Brasil e o ISEB era um órgão oficial.

É no período da "encampação juscelinista" que Adalgisa pareceu se aproximar do grupo. Conforme apontou Navarro de Toledo (1977) o nacionalismo foi a ideologia hegemônica no interior do ISEB, particularmente durante o período que correspondeu ao governo JK. Assim, mesmo não fazendo parte do rol de integrantes oficiais do ISEB, a colunista do "Última Hora", em artigo de 1958, defendeu a instituição. Ao mesmo tempo, conforme os acontecimentos políticos comprovaram, Adalgisa Nery estabeleceu uma perspectiva bastante lúcida da situação que se esboçava:

\footnotetext{
${ }^{4}$ Figuravam, ainda, nos conselhos consultivo e curador: Heitor Villalobos, Horácio Lafer, Santhiago Dantas, Sérgio Millet, Miguel Reali, Fernando de Azevedo, Luiz Viana Filho, Lucas Lopes entre outros.
} 
Para os detratores do ISEB deve acontecer o seguinte: a comunidade brasileira permanecer analfabeta, os poucos que saírem da cegueira espiritual devem ficar perdidos na ignorância das causas e efeitos que nos afligem. Apenas alguns têm o direito de penetrar, com o consentimento especial do Presidente da República, na Escola Superior de Guerra, onde os problemas nacionais são debatidos em segredo e onde o reconhecido espírito golpista fabrica uma consciência nacional. É simplesmente isso, os inimigos de Anísio Teixeira e os adversários do ISEB perseguem interesses que não são os do Brasil. (Última Hora, 2 jun. 1958).

Em tal artigo intitulado "Adversários de Anísio e do ISEB perseguem objetivos antinacionais", ela traçou um histórico elogioso do instituto e saiu em defesa do educador Anísio Teixeira, já que ambos haviam sido acusados de comunistas. Adalgisa Nery os defendia sob a égide do nacionalismo.

Aliás, em tempos de Guerra Fria a 'acusação' de comunista funcionava como fator de desqualificação naquele contexto. Um episódio sintomático foi a polêmica estabelecida com o todo poderoso da imprensa nacional, Assis Chateaubriand.

O dono dos "Diários Associados", rede de comunicação que incluía jornais, revistas e estações de rádio e televisão, acusou Adalgisa Nery de opinar, "não por conta própria, mas pela pressão dos elementos sovietisantes - basta ver o diário onde ela escreve." (O Jornal, 19 jan. 1955) Assis Chateaubriand a tachava de estar "a serviço de um complot comunista" em sua resposta ao artigo "Arranjos políticos" escrito pela jornalista. Em tal artigo, publicado em 11 de janeiro de 1955, Adalgisa afirmou que o cargo de Chateaubriand no Senado havia sido conquistado através de uma intrincada transação com os senadores Victorino Freire e Antônio Bayma do Maranhão. Como não havia conseguido eleger-se pela Paraíba, a jornalista sugeriu com seu tom característico de indignação e sarcasmo, que o novo senador havia "comprado" o cargo no Senado em troca "de um ótimo apartamento com ar refrigerado e um ou dois cadillacs." (Última Hora, 11 jan. 1955).

Adalgisa Nery e Chateaubriand mantinham laços de amizade até então. O exagero nos argumentos de Chateaubriand pode ser notado no próprio título do texto publicado em "O jornal": "Uma matrona tarada." Nele, o imortal então recém eleito para a Academia Brasileira de Letras defendeu-se da insinuação ao mesmo tempo em que acusou grosseiramente, não apenas a profissional do jornalismo, mas a mulher Adalgisa Nery: "quem calunia sem ter provas deve ser um tarado. E é o que miseravelmente fez a vulgar sexagenária [...] em sua malvadez de virago." Sem nomear o alvo de tanta hostilidade, ressaltou a filiação política da acusada: "É a imundice comunista, é a torpeza dos brasileiros assalariados de Moscou." 
Adalgisa tinha por volta de 50 anos nessa ocasião. A referência à idade é posta como algo negativo, e certamente não ocorreria se se tratasse de um homem. Da mesma forma, a suspeita de lesbianismo foi inferida, talvez, pelo estilo contundente dessa mulher, em contraposição às qualidades vistas como femininas, tais como delicadeza, doçura etc.

Em 14 de janeiro, quatro dias antes de ter sido 'acusada' de comunista, publicou-se, também em "O Jornal", um "a pedidos" sob o título "Retrato retocado", assinado por "Adalgiso Neruba." Os insultos não foram menos intensos: atingiram primordialmente Adalgisa em sua conduta como mulher, no campo da sua vida privada; a chama de "velha beldade" que:

Acalmou-se, ao cabo de longa e varia estrada, por cujas margens foi deixando, tombada e murcha, outrora ereta plêiade de paladinos. Expulsa do derradeiro conúbio, reformada com vencimentos, tenta hoje reformar o mundo. Foi expulsa por péssima conduta e como falsa esposa. Há dias zangou-se porque um burocrata lançou-lhe por trás o que só pela frente agora deseja receber. [...] Raro é o dia em que ela não dá palmatoadas na pobre humanidade. Dar tem sido seu fado. Não de graça, pois tendo dado toda vida, hoje tem mais do que antes e nunca. Numa de suas últimas conversas públicas, ela, que tanto amara as privadas, lembrou recente salto à Paris. Como se divertiu! E como mudaram os tempos! Não nos disse, porém, porque voltou às pressas e descaideirada. E sem níquel. É que, cisne no derradeiro gemido, nem de graça conseguia realizar o seu destino dadivoso. Havia que pagar! Franqueando-se alucinadamente, endemoninhadamente, em fundas noites bagunçosas [...] Voltou tinindo, insatisfeita, inconsolável. Inacabada. Daí o azedume de seus nús diários. Precisamos recauchutála, ou, pelo menos, trocar-lhe a lona. Ou entulha-la de francos e despacha-la aos latagões de empino. (sic. O Jornal, 14 jan. 1955).

Certamente a alcunha "Adalgiso Neruba" é uma referência ao escritor comunista chileno Pablo Neruda (1904-1973). O texto é repleto de metáforas preconceituosas, frases dúbias e insultos extremamente grosseiros. Em seu ataque inicial, o acusador resgata, simbolicamente, a posição de Adalgisa em períodos anteriores, dos tempos do Estado Novo, por exemplo. Assim como levantou suspeita quanto ao casamento com Lourival Fontes, então recentemente desfeito. Insinuou com malícia e ambigüidade seu trabalho no jornal. $O$ ataque é carregado de simbolismos. A ofensiva atingiu com argumentos distorcidos a vida pessoal de Adalgisa Nery. Talvez uma mulher não pudesse valer-se de tamanha ousadia 
criticando atitude política do "rei do Brasil"; talvez fosse demais para os brios de Chateaubriand, que se arriscava na política institucional, então recentemente. Enfim, o texto expressou forte preconceito de gênero.

O biógrafo de "Chatô", Fernando Morais, afirmou que ele decidira não responder às críticas sobre a sua chegada ao Senado. Até ler a versão de Adalgisa: "[...] o dono dos Associados rabiscou dez linhas em um pedaço de papel, chamou o redator Maurício Waitsman e mandou publicar com uma 'a pedidos' na primeira página do Diário da Noite." (MORAIS, 1994, p. 568).

Uma foto da colunista com o título "Morrer, mas não apodrecer" ilustrou a capa do "Última Hora" do dia 17 de janeiro de 1955. No artigo, Adalgisa defendeu-se citando os nomes dos envolvidos nas manobras desaprovadas por ela. E finalizou, metaforicamente, como lhe era peculiar: "Prefiro morrer de fome, em pé num deserto, a viver e engordar-me comendo agachada num prato de caviar colocado aos pés de homens que só são homens por erro do sistema glandular." (Última Hora, 17 jan. 1955).

O episódio provocou comentários de órgãos importantes da imprensa carioca, que se posicionaram solidarizando-se com a jornalista, tais como o "Diário de notícias", o "Correio da manhã" e "O Globo."

A polêmica foi tratada na revista norte-americana "Time Magazine" de 07 de fevereiro de 1955. Os itens "Insultos publicados", "Escândalo picante" e "Uma alma fria" da seção "O hemisfério" procuraram descrever minuciosamente a intriga. $\mathrm{O}$ texto apresentou certa dose de veneno:

O que fez o escândalo irresistivelmente picante foi que Adalgisa e Chatô eram muito bons amigos. Durante os anos em que a brilhante e ornamental Adalgisa presidia os salões da alta sociedade do Rio, Chatô foi um freqüente e admirado convidado. No ano passado, depois que Adalgisa separou-se do segundo marido, Chatô presenteou-a com uma cara viagem à Europa; Chatô a acompanhou em Paris e fizeram a cidade juntos. (tradução nossa) ${ }^{6}$

\footnotetext{
${ }^{5}$ Acervo “Adalgisa Nery” depositado na Fundação Casa de Rui Barbosa, Rio de Janeiro. Pequenos recor tes dispostos numa folha com os dados anotados à lápis.

${ }^{6}$ Time Magazine de 7 fev.1955, p. 27, no original, seção "The hemisphere" e os itens: "Insulting publicher", "Piquant scandal" e "A cold soul."
} 
A situação provocou a reação de militares maranhenses que ofereceram um almoço no clube da Aeronáutica em apoio à jornalista insultada. "Nós, maranhenses lhe somos gratos, dona Adalgisa", foi manchete da edição do "Última Hora" de 21 de janeiro de 1955. A notícia do almoço trouxe a foto de Adalgisa na capa e o texto à página 8:

Como desagravo pelos insultos feitos à sua honorabilidade de mulher $\mathrm{e}$ à sua dignidade de jornalista em um 'a pedido' de 'O jornal', a nossa colunista Adalgisa Nery, responsável por 'Retrato sem Retoque', uma das colunas mais lidas e acatadas da imprensa carioca, foi homenageada ontem.

A matéria informou que tal iniciativa foi articulada pelo chefe do gabinete do ministro da Aeronáutica, coronel Armando de Menezes, e reproduziu falas da jornalista em agradecimento, finalizando: "Finda a homenagem um grupo de oficiais ofereceu-se para acompanhar Adalgisa Nery até a sua residência numa escolta cordial.”

O episódio com Chatô, além de ter significado a quebra de uma relação estabelecida desde o Estado Novo e que envolvia boa dose de interesses, teve desdobramentos que ajudaram a delimitar o campo político no período seguinte. Para além da troca de insultos, Adalgisa Nery era herdeira da tradição política de Vargas e a briga com Chateaubriand constituiu a quebra de certa aliança. No plano pessoal, Adalgisa Nery legitimava-se como jornalista, angariando força política com sua postura nacionalista e getulista.

Somado à CPI do "Última Hora" e às especulações sobre a nacionalidade de Samuel Wainer, o episódio com Chatô serviu como fator de polarização política na imprensa.

O ano de 1955 estava apenas no começo e seria ainda marcado por sérios conflitos políticos, como o episódio de 11 de novembro de 1955, conhecido pejorativamente como "Novembrada", um marco de polarização no que tange às Forças Armadas. Entendido como um golpe preventivo deflagrado pelo então ministro da Guerra Marechal Henrique Teixeira Lott, o evento garantiu a posse de JK e João Goulart, funcionando como importante fator de convergência de forças. A crise de novembro significou um movimento de resistência em defesa da legalidade: a capital do país foi ocupada por tropas do Exército; o Congresso aprovou a decretação de estado de sítio e assegurou a presidência a Nereu Ramos, presidente do Senado, até a posse dos eleitos em 31 de janeiro de 1956. (FERREIRA, 2005, p.253-261).

As páginas do "Última Hora" acompanharam o desenrolar dos acontecimentos incessantemente: naquele dia 11, o jornal circulou em quatro edições. Nos dias conturbados 
de novembro, através da sua coluna, Adalgisa Nery elogiou os militares legalistas e os políticos civis que os apoiaram na Câmara Federal.

Como afirma João Martins Filho, o 11 de novembro mostrou que "os militares não tomaram o poder em meados da década de 1950 não por falta de vontade ou confiança, mas porque tanto o campo político civil como o militar estavam profundamente divididos." (MARTINS FILHO, 2003, p.120).

No nível internacional a colunista do "Última Hora" comentou em 25 de novembro de 1955 uma reportagem de Daniel Jams publicada no jornal "Herald Tribune", informando, indignada, que o jornalista norte americano escrevera que teria havido no Brasil um movimento político de "coalizão nacionalista-comunista" e comparava a situação brasileira com a Guatemala. ${ }^{7}$

Em tempos marcados pela Guerra Fria o continente americano foi abalado pela Revolução Cubana no final dos anos 1950, o que, de algum modo, exigiu o posicionamento de políticos e intelectuais. ${ }^{8}$

No Brasil o exemplo cubano, assim como a luta dos congoleses na África, recebeu apoio dos nacionalistas na ocasião da I Convenção do Movimento Nacionalista da Guanabara em 1960, quando Adalgisa Nery era candidata ao cargo de deputada constituinte do novo estado. Aliás, como reconhecida nacionalista, Adalgisa Nery foi escolhida para presidir o Movimento Nacionalista da Guanabara. (Última Hora, 11 ago. 1960) O discurso proferido por ela durante a citada convenção foi registrado nas páginas do jornal em que era colunista e no item "Ambiente internacional", assumiu:

Lutas de liberação, muitas assemelhadas à nossa, estão ocorrendo noutros países subdesenvolvidos. Essa luta contra o subdesenvolvimento, sem dúvida, apresenta variedades de forma e até de conteúdo em cada caso. Em suas linhas mestras, contudo, estão irmanadas. Então, é compreensível que todos esses povos que na mesma época desfraldam bandeiras libertadoras, simpatizem uns com

\footnotetext{
${ }^{7}$ Jornal "Última Hora" de 25/11/1955, sob o título "Falta de respeito." O governo de Juan Arbenz promoveu a reforma agrária na Guatemala atingindo terras não cultivadas da United Fruit Company, empresa cujo líder de então no país havia sido da seção da América Latina do Departamento de Estado norte americano. Em junho de 1954 a Guatemala sofreu um golpe com explícito apoio armado dos EUA sob o argumento de combate ao comunismo, este último, condenado por uma dócil Conferência Interamericana ocorrida em março daquele ano. Sobre esse aspecto, ver: Kiernan (2009, p. 369).

${ }^{8}$ No segundo semestre de 1960 o casal Jean-Paul Sartre e Simone de Beauvoir, após visita a Fidel Castro em Cuba foi recebido como celebridade no Brasil. Ver: Romano (2002). O jornal "Última Hora" publicou uma série de reportagens de Sartre intituladas "Furacão em Cuba", que foram transformadas em livro lançado no Super Shopping Center de Copacabana, onde Sartre autografou cerca de 800 exemplares. Sartre proferiu palestra sobre o colonialismo na sede do ISEB. (Última Hora, 27 ago.1960).
} 
os outros [...] eis porque no Brasil, é enorme o prestígio de Fidel Castro que tomou a frente de seu povo para libertar Cuba de uma secular dominação estrangeira mal dissimulada pelas fórmulas exteriores. (Última Hora, 23 ago.1960).

A declaração de princípios aprovada ao fim do encontro lançou os pontos defendidos pelos participantes e entre eles, solidariedade aos países subdesenvolvidos e ao movimento em Cuba. O "Última Hora" deu especial atenção ao encontro que se posicionava apartidário, apesar do grupo declarar-se em apoio à candidatura de nacionalistas como João Goulart. (Última Hora, 20 ago. 1960) Tais posicionamentos marcaram o momento político eleitoral, quando Adalgisa Nery elegeu-se deputada constituinte pelo PSB, tornando-se líder de seu partido.

Em agosto de 1961, a nova tentativa de golpe causada pela renúncia de Jânio Quadros também contribuiu para o acirramento das posições, principalmente no seio das Forças Armadas.

No dia 22, às vésperas da renúncia de Jânio Quadros, Adalgisa Nery denunciou em sua coluna jornalística, sob o título "Os maquinistas de agosto", uma reunião da alta patente do exército chefiada por Cordeiro de Farias, prevendo:

Repete-se em agosto de 1961 a mesma manobra havida em agosto de 1954, em que CL [Carlos Lacerda] foi arma usada contra Getúlio Vargas pelos interesses antinacionais. A máquina do regime de exceção está sendo movimentada pelos mesmos maquinistas de agosto de 1954. A força total vem de fora do Brasil contra o Brasil. (Última Hora, 22 ago. 1961).

Jânio Quadros havia instigado a crise antes mesmo de sua renúncia. Adotou medidas incompatíveis com a importância do cargo que ocupava, tais como as proibições do lançaperfume nos bailes de carnaval, do uso de maiôs 'cavados' nos concursos de misses e das brigas de galo. A condecoração do ministro cubano Ernesto "Che” Guevara em agosto de 1961 provocou a ira de seus opositores políticos e das forças conservadoras. A hipótese de que, por erro de cálculo, Jânio Quadros seria solicitado para voltar ao governo com mais poderes, merece ser aludida. De fato, o episódio da renúncia gerada por pressão do que Jânio chamou de "forças terríveis", não ficou esclarecido, mesmo posteriormente. (MAYER; XAVIER, 2000). 
Deflagrada a crise, os ministros militares manifestaram-se contrários à posse do vicepresidente João Goulart, a quem o cargo pertencia por direito, segundo a Constituição Federal de 1946. Em visita oficial à República Popular da China, Goulart era acusado pelos ministros Odílio Denys do Exército, Silvio Heck da Marinha e Grum Moss da Aeronáutica, de apresentar posições "claramente subversivas e esquerdistas." (Manifesto dos ministros militares, apud, LABAKI, 1986, p.149).

No estado da Guanabara a conjuntura política de agosto e setembro de 1961 teve reflexos particulares. O Rio de Janeiro já não era a capital federal, entretanto, uma elite política permanecia envolvida intensamente com os episódios da vida nacional. O Estado da Guanabara, embora tenha existido por um breve período (1960-1975), serviu de palco para importantes acontecimentos, cujos reflexos marcaram, decisivamente, a história políticoadministrativa do Brasil. Até meados de 1970, pode-se falar de uma certa ambigüidade ao nos referirmos à situação da Guanabara: por um lado, uma cidade-estado e, por outro, continuava a abrigar uma parte dos órgãos de governo da capital transferida, já que com a regulamentação de abril de 1960, houve a transferência dos serviços federais para a Guanabara.(MOTTA, 2000).

Se por um lado a Assembléia Legislativa do novo estado tratava de assuntos ligados diretamente à Guanabara, por outro, havia uma relação bastante íntima com os quesitos da conjuntura política nacional. Até porque, o primeiro governador do Estado, Carlos Lacerda, foi pivô de diversas situações que culminaram em sérias crises, principalmente de nível nacional. (MOTTA, 2000).

Como no caso da crise política de agosto de 1961, quando Carlos La cerda tratou de calar as vozes que se voltavam contrárias à intervenção das Forças Armadas, mobilizando o aparato policial do Estado para reprimir os movimentos pela legalidade manifestados em diversos pontos da cidade, principalmente em frente ao busto de Vargas na Cinelândia. Diversos setores declararam greve: trabalhadores dos transportes, bancários, estudantes, empregados do comércio, da indústria e do setor financeiro formaram o movimento grevista nas ruas do Rio de Janeiro, transformadas em palco de protestos e comícios próGoulart. (FERREIRA, 2005, p.297).

Como dono de jornal, Lacerda procurou divulgar a falsa informação de calmaria, tranqüilidade e paz social. Essas imagens não condiziam com a realidade das ruas do Rio de Janeiro. No que diz respeito à imprensa, várias sedes de jornais foram invadidas por censores, os jornais que se posicionavam notadamente favoráveis à posse de Goulart foram impedidos de circular ou censurados, tais como "Correio da Manhã", "O Jornal", "Diário de Notícias" e "Última Hora." (CAMPOS, 1996).

Adalgisa Nery publicou, sob o título "Sopa e ajantarado", a denúncia sutil da censura sofrida. Ela escreveu sobre a "arte de bem comer" e fez comentários quase absurdos, como, 
por exemplo, referindo-se à "carne de baleia, alimento farto em calorias e de fácil aquisição" e a receita de uma sopa, no mínimo esquisita, indicada de "acordo com o nosso clima tropical." (Última Hora, 30 ago. 1961) No dia seguinte, escreveu sob o título: "Importantíssimo problema: a Moda", onde discutiu grifes e tendências. No fim do artigo, o texto: "N.R - Este jornal ainda estava sob censura policial, atingindo naturalmente a colunista de Retrato sem Retoque, ilegalmente imposta pelo Sr. Carlos Lacerda, foi abolida, é preciso dar essa explicação ao leitor." (Última Hora, 31 ago.1961).

Aquela era uma mostra da censura que a imprensa sofreria após o golpe vitorioso de abril de 1964. Naquele agosto de 1961, já como deputada eleita, o artigo censurado no qual denunciava as atitudes golpistas do governador da Guanabara, foi lido na tribuna da assembleia legislativa estadual pelo deputado Hércules Correia, comunista eleito pelo PTB, que informou a censura sofrida pelo "Última Hora."

Nos dias que se seguiram, Adalgisa Nery saiu em defesa da resistência democrática encabeçada pelo governador gaúcho Leonel Brizola no sul do país, referindo-se à tentativa de se instaurar uma "ditadura branca." Em seus textos, tratou com agressividade os chefes militares envolvidos, e entre os adjetivos, chamou-os de "indisciplinados, deflagradores de badernas comandados pelo anarquista CL, vermes fardados, traidores do povo que merecem o repúdio e a repugnância do povo." (Última Hora, 2 set. 1961).

Já na câmara estadual, no dia 14 de setembro de 1961, quando o país encontrava -se "sob uma nova forma de governo, com a restauração súbita, quase às cegas do sistema parlamentarista", a deputada denunciou num longo discurso: "Começou mal o ensaio de parlamentarismo com cheiro de quartelada [...]." Num outro trecho referiu-se às ações do governador Calos Lacerda:

Sem estado de sítio decretado, nem nenhuma base legal, mandou censurar jornais, apreender edições, invadir e ocupar militarmente redações, prender jornalistas e líderes sindicais e metê-los em cubículos infectos juntamente com criminosos comuns. ${ }^{9}$

Nelson Werneck Sodré, militar e intelectual das esquerdas, escreveu muito proximamente aos acontecimentos que antecederam ao golpe, figurando como depoentetestemunha do abril de 1964. Assim, o impasse causado pela renúncia do presidente Jânio Quadros acirrou ainda mais a disputa das forças que se esboçavam no contexto político

\footnotetext{
${ }^{9}$ Anais da Assembléia Legislativa do Estado da Guanabara, VI: setembro de 1961, p. 1705-1706, “Sobre o governador Carlos
} Lacerda". 
nacional. No que tange à instituição militar, Sodré falou em "ditadura frustrada" e referiu-se a "uma anomalia curiosa: vencidos pareciam vencedores", afinal, os que asseguraram o regime democrático, foram perseguidos. O parlamentarismo foi uma espécie de condenação aos defensores da legalidade: "premiava os golpistas, e punia os legalistas." (SODRÉ, 1965, p. 386).

Marco importante para o período que se seguiu foi a fundaçã o oficializada em fevereiro de 1962, do Instituto de Pesquisas e Estudos Sociais - Ipês, entidade que congregava o empresariado paulista e carioca que via com desconfiança a ascensão de Goulart. O Ipês atuava em associação com o Instituto Brasileiro de Ação Democrática - IBAD fundado em 1959. Essas instituições merecem ser entendidas como parte da estratégia de mobilização das forças golpistas junto à sociedade civil brasileira. Atuando em diversas frentes e de maneiras variadas, valendo de financiamentos razoavelmente abundantes, e multiplicandose por todo o país, o "complexo Ipês/IBAD" é entendido por René Dreifuss como importante difusor ideológico, estimulando a inquietação política, o que caracterizaria o golpe vitorioso de 1964, como civil-militar. (DREIFUSS, 1981).

Para tanto, esses organismos em consonância com a construção de uma rede de apoio dentro das Forças Armadas, auxiliaram na formação de uma opinião pública que paulatinamente fosse estimulada a dar apoio ao golpe que se esboçava.

Deste modo, a renúncia do presidente Jânio pode ser entendida como um marco importante na medida em que tal circunstância auxiliou na demarcação dos campos de atuação das forças golpistas. O desempenho dessas forças teve como resultado o sucesso do golpe definitivo em abril de 1964, quando essa mesma opinião pública, que resistiu à tentativa golpista em agosto de 1961, estaria 'convencida' o suficiente para apoiar a intervenção dos militares, mostrando que o "tumor fétido" referenciado metaforicamente pela jornalista Adalgisa Nery quando tratou da permanência dos golpistas em suas atividades militares, não havia sido mesmo curado.

Através de sua coluna no "Última Hora" Adalgisa Nery denunciava, de modo bastante lúcido, os organismos e personalidades que efetivariam o golpe em 1964. Como uma voz de acusação às atividades do IBAD, Adalgisa Nery escreveu em "Aulas de domesticação" sobre as artimanhas do órgão, suspeitíssimo, segundo a colunista. Os "depenados papagaios reacionários" falam em "infiltração comunista em todos os setores da vida brasileira." Especificamente na Guanabara, "os papagaios alimentados com dólares falam até formarem calos nas cordas vocais." Assim, com "ousadia descomunal" a reação processa, "nos cinemas, nos colégios particulares, nas igrejas, nas enfermarias e nos cursos oficializados do governo" intensa movimentação de propaganda anticomunista: 
Nos cinemas manufaturaram filmes documentários com verdadeira arte de foto-montagem. Cortaram cenas de vários e num só resumiram sua intenção. A propaganda fascista anda solta, fantasiada de democracia cristã. E como esta qualidade de democracia cristã exige enormes quantias, o poder econômico espalha dinheiro às cascatas (...) O que assistimos é uma terrível e melancólica propaganda norte americana invadindo todos os setores da vida nacional. E tal coisa, evidentemente, não trás nenhum benefício ao nosso país, uma vez que brasileiros não podem ser absolvidos nem domesticados pelo comunismo ou capitalismo ianque, e sim, pelos sentimentos autenticamente nacionais. A invasão do IBAD na vida dos brasileiros torna-se no momento tão dramática e fatal para o Brasil como se estivéssemos dominados pelo 'colera morbus.' (Última Hora, 5 out. 1962).

Adalgisa afirmou ter recebido denúncias de que, num curso técnico de administração, as provas foram interrompidas para a exibição de um filme produzido pelo IBAD.

A jornalista Denise Assis (2001) mergulhou numa vasta documentação do Ipês doada ao Arquivo Nacional em 1972. Além de atas e relatórios, ela debruçou-se sobre os filmes - com qualidade técnica similar às produções estrangeiras do período - produzidos pelo órgão: arma fundamental de propaganda ideológica anticomunista acionada pelo Ipês e exibida em salas de cinema de todo o país:

Mensagens que pregavam o anticomunismo escancarado, a modernização das empresas e o engajamento do empresariado nessa luta constituíam a tônica dos roteiros. O autor se esmerava no esforço de comover a burguesia e a classe média, sem as quais não haveria apoio ao golpe. (ASSIS, 2001, p.42).

Da mesma forma os filmes eram exibidos em 'cinemas ambulantes': caminhões com projetores que percorriam favelas e a periferia das cidades; clubes, associações, sindicatos, igrejas, praças públicas e até em programa de televisão: a propaganda doutrinária não media esforços para atingir o maior público possível.

Denise Assis refere-se também aos convênios estabelecidos entre o Ipês e instituições de ensino, sindicatos, gráficas e editoras, mostrando a larga abrangência de ações do órgão. A 
autora defende a ideia de que o Ipês tinha por objetivo a preparação da sociedade brasileira para não reagir ao golpe, empenhando-se na produção de um consenso. Para tanto, comprava espaço na mídia escrita, falada e televisiva, inclusive com programa de TV que veiculava claramente a ideologia golpista.

Neste sentido, Adalgisa Nery foi voz constante de denúncia do complexo Ipês/IBAD nas páginas do "Última Hora" denunciando, inclusive o discurso anticomunista consubstanciado em entidades como a "Ação Democrática Parlamentar, bloco interpartidário surgido no primeiro semestre de 1961, com o objetivo de combater a infiltração comunista na sociedade brasileira" (LAMARÃO, 2000), além da "Cruzada Brasileira Anticomunista."

Entendido como principal elemento unificador da oposição ao governo João Goulart, o temor anticomunista e suas organizações são analisados por Rodrigo Patto Sá Motta no capítulo "João Goulart e a mobilização anticomunista de 1961-64." A renúncia de Jânio Quadros, em agosto de 1961, é episódio importante, já que o vice-presidente João Goulart, "era um político conhecido por cultivar ligações com a esquerda." (SÁ MOTTA, 2006, p. 129) O autor refere-se às organizações anticomunistas de experiências mais efêmeras: as vinculadas aos valores cristãos, as que eram claramente terroristas, como o Movimento Anticomunista - MAC, as inseridas nos meios parlamentares, como a "Ação Democrática Parlamentar", além de diversas entidades femininas que "conferiam um apelo especial à mobilização das direitas, devido à força simbólica de sua presença no cenário político, representando a figura materna, o lar e a dona-de-casa, em resumo, a família." (SÁ MOTTA, 2006, p. 133).

Entretanto, o chamado complexo Ipês/IBAD teve atuação mais efetiva e influente no período em questão. Tais entidades "desempenharam o papel de induzir a estruturação de novos grupos anticomunistas.” (SÁ MOTTA, 2006, p. 133). Até a realização do plebiscito que restaurou o presidencialismo em janeiro de 1963, Jango sustentou algum equilíbrio no que diz respeito às forças que o apoiavam. Conservadores e moderados esperavam uma saída para as crises política e econômica. "A trégua começou a ser rompida e os moderados passaram a engrossar o coro dos direitistas radicais, que não haviam reduzido o tom da campanha anticomunista." (SÁ MOTTA, 2006, p. 136).

No decorrer de 1963 as dificuldades de governabilidade agravaram-se. No quesito economia, o avanço excessivo dos índices de inflação provocava o aumento do custo de vida e a carestia. Na área política, o agravamento se deu pela radicalização das posições de figuras que tinham vínculos com o governo, como Leonel Brizola, que, exigindo posições mais claras do presidente, ao mesmo tempo agia em prol das reformas como governador do Rio Grande do Sul e em seguida como deputado federal. Uma onda grevista no país sugeria a infiltração dos 'vermelhos' entre os trabalhadores, acirrando as insatisfações sociais. Enfim, 
a complexidade da situação foi ardilosamente utilizada pela reação conservadora que vinculou a crise geral do país com o perigo comunista.

Como observa Sá Motta: "Os líderes do golpe tinham uma avaliação imprecisa da extensão da ameaça comunista, apesar de acreditarem nela. Ainda assim, se esforçaram para convencer o público de que os bárbaros estavam à porta." (SÁ MOTTA, 2006, p. 146).

A idéia do perigo comunista, ameaçando a democracia e colocando em risco a família e a moral cristã, teve como importante meio de divulgação entre as mulheres da elite, a Campanha da mulher pela democracia - CAMDE. O órgão criado em 1962, cuja sede era uma igreja católica carioca, teve vínculos com o complexo Ipês/IBAD.

Muito provavelmente, "as senhoras inteiramente ignorantes das questões econômicas e sociais, e até mesmo desconhecendo a composição do sistema democrático", de que trata Adalgisa Nery em "Política em sacristias", sejam as representantes da CAMDE. As tais, "amontoam-se nas sacristias e saem como guerrilheiras combatentes do comunismo." Tal artigo é mais um exemplo da clareza com que Adalgisa Nery percebia aquela conjuntura:

Suas culturas cingem-se à leitura de certos órgãos da imprensa 'sadia' sustentada pelo poder econômico estrangeiro com a finalidade exclusiva de domesticar a mentalidade da classe média, uma vez que a dita classe alta, a privilegiada, funciona de pleno acordo com os interesses anti-nacionais, pois que sua sobrevivência depende das migalhas a ela distribuídas pelos grupos econômicos internacionais. (Última Hora, 11 set. 1962).

A CAMDE possuía um caráter também assistencialista atuando em favelas e desenvolvendo um trabalho social ao mesmo tempo em que procurava reproduzir seus conceitos. "Mensagens políticas e orientações desse tipo vinham em impressos de fácil leitura, alguns até mesmo em quadrinhos, sempre atraentes e direcionados às mulheres carentes e seus maridos, em geral operários." (ASSIS, 2001, p.55).

De forma cada vez mais efetiva, na visão dos conservadores, os que eram favoráveis ao governo e/ou defendiam mudanças na estrutura social vigente (nacionalistas, socialistas e trabalhistas), ou seja, "o bloco nacional-reformista" eram acusados de comunistas. (DREIFUSS, 1981).

Dentro dessa perspectiva Adalgisa Nery pode ser interpretada como intelectual nos moldes estabelecidos pelo italiano Antonio Gramsci, cujo enfoque marxista coloca os 
intelectuais como conservadores ou transformadores da sociedade. Em sua teoria da transformação social os intelectuais desempenham um papel estratégico, e a ênfase na função dos intelectuais nos vários âmbitos da vida social e também na história é um dos aspectos mais originais do pensamento gramsciano, que valorizou os agentes sociais que exercem atividades de natureza intelectual ao mesmo tempo que ampliou o próprio conceito de intelectual. (GRAMSCI, 1982, p.6-7).

Valendo-se da ideia do intelectual como categoria orgânica de cada grupo social em prol da hegemonia ou de luta por ela, Adalgisa Nery estabeleceu-se como agente social em defesa da transformação da sociedade. Neste sentido, o suicídio de Vargas marcou seu posicionamento à favor dos interesses nacionais, denunciando as mazelas sociais do Brasil de então.

"Boato, arma do pânico" foi o título do último artigo assinado por Adalgisa Nery no jornal "Última Hora" e saiu no dia primeiro de abril de 1964. Nele ela citou uma série de boatos sobre a política brasileira de então:

Não são com esses boatos, arma de desagregação no país, que a fome, o desemprego, a doença e a revolta social são anuladas da vida nacional. Homem não é aquele que veste calças ou farda utilizando-as como cérebro. Homem é o que usa o cérebro, o que enfrenta com dignidade a realidade dos fatos e procura com a força do cérebro construir e unir os espíritos assustados. O boato é irmão gêmeo da carta anônima. É arma vil do covarde que espalha o pânico e o terror para deles tirar vantagens. (Última Hora, 1 abr. 1964).

Quando a "Última Hora" chegou às bancas de jornal, no dia primeiro de abril de 1964, os fatos mostravam que a agitação não era mero rumor. $O$ boato transformara -se em realidade e o país sucumbia ao golpismo.

Naquela noite, a sede do "Última Hora" foi depredada e incendiada. Samuel Wainer exilou-se na embaixada do Chile no dia primeiro de abril e deixou o país no início de maio. Da mesma forma, considerada uma instituição subversiva pelas forças vitoriosas de abril de 1964, a sede do ISEB foi invadida e depredada. Assim como a sede da União Nacional dos Estudantes - UNE, "depois de destruídas, tiveram seus documentos, arquivos e publicações consumidos pelo fogo." (TOLEDO, 1977, p.191). 
No dia 2 de abril as ruas do centro do Rio de Janeiro foram tomadas pela gigantesca manifestação da "Marcha da Família com Deus pela Liberdade" em apoio e comemoração à vitória do golpe.

Adalgisa Nery não freqüentou a Assembléia Legislativa nos dias que se seguiram. Seu nome não figurou nas primeiras listas de cassação, apesar de vários correligionários do PTB da ALEG terem perdido seus direitos políticos. No entanto, em outubro de 1969, após declarações polêmicas na imprensa, e convocações para depor no Ministério do Exército, teve os direitos políticos cassados pelo regime militar.

\section{Considerações finais}

O período compreendido neste artigo foi de intensa polarização política, reflexo da Guerra Fria, acirrada na América Latina após 1959, quando os jovens revolucionários cubanos desbancaram a velha dominação norte-americana no país, provocando o alerta incondicional dos EUA, afinal, a ameaça localizava -se a alguns quilômetros de sua costa. Nos anos seguintes, após o alinhamento cubano com os soviéticos, a potência capitalista era ameaçada em seu próprio continente. Entretanto, a pedra fundamental da luta dos revolucionários cubanos era a emancipação nacional norteada pelo antiimperialismo.

Naquele contexto, o movimento nacionalista foi intensificado no Brasil, e a mera conexão com os movimentos de defesa dos interesses internos soava como alinhamento comunista. O propósito deste artigo foi mostrar este panorama de tensões expresso na imprensa nos anos que antecederam ao golpe civil-militar de abril de 1964, por meio da análise da atuação de Adalgisa Nery como colunista e, por conseguinte, conforme a concepção gramsciana dos intelectuais, como intelectual orgânico, já que, após o desaparecimento de Vargas, esteve vinculada a um projeto emancipador das classes subalternas através do discurso nacionalista. Como jornalista e deputada ocupou a função de agente em prol da transformação social: fez coro junto aos progressistas.

Com tom irônico e acusador, os ataques de Adalgisa Nery nas publicações do "Retrato sem Retoque" radicalizam-se no início da década de 1960. Portadora de discurso nacionalista desde o início da carreira no "Última Hora" em 1954, Adalgisa era reconhecida como representante do nacionalismo, principalmente por conta de sua condição de formadora de opinião, de personalidade pública vinculada a um órgão da grande imprensa. 
Sob os ares da democracia, Adalgisa Nery saiu em defesa dos interesses do Brasil e da ética na política institucional. Explicitou suas posições de modo intenso na imprensa. Reconhecida, conquistou um cargo na política institucional. Num campo político contextualizado pelas artimanhas da Guerra Fria, pelos jogos de influência externa, somados à paulatina polarização político-ideológica, o vínculo de Adalgisa Nery com o nacionalismo-getulista, reforçava a sua identidade com as forças de esquerda.

Ao mesmo tempo, Adalgisa via a figura de Jango como herdeiro político de Vargas, propenso a realizar as reformas necessárias para a superação do subdesenvolvimento. De uma maneira geral, o cenário político brasileiro nos anos 1960 foi marcado pela polarização entre forças de esquerda, que defendiam reformas de cunho social, e as conservadoras, que salientavam a necessidade de contenção das reivindicações trabalhistas.

Adalgisa Nery teve posição de destaque durante a ditadura do Estado Novo assim como no governo democrático de Vargas; iniciou a carreira jornalística no mesmo ano do trágico desaparecimento de Getúlio; tornou-se irredutível defensora dos interesses nacionais num tempo de intensa polarização política, inspirando-se no socialismo. Após cerca de seis anos atuando no jornalismo, Adalgisa Nery estabeleceu, então, como deputada, mais um veículo para expor suas idéias e posições políticas.

Seu principal palanque foi a coluna jornalística no "Última Hora": a popular e bemsucedida colunista converteu seus leitores em eleitores. A partir de então os textos de sua coluna dialogavam com seu trabalho no parlamento da Guanabara. Em algumas circunstâncias, nas sessões parlamentares, fez a leitura de seus artigos publicados, assim como incorporou a posição de deputada na coluna "Retrato sem Retoque" em várias ocasiões. A imprensa tornou-se espaço de diálogos constantes com seus eleitores, que em diversas ocasiões lhes faziam denúncias, abordadas em sua coluna.

Desde o início de seu trabalho no "Última Hora", por conta de seus posicionamentos, argumentos e ataques, Adalgisa era acusada de comunista. À medida que as forças golpistas pareciam mais propensas ao golpe definitivo, simultaneamente ao acirramento dos debates que diziam respeito ao aumento da participação popular, Adalgisa Nery posicionava-se ao lado das forças consideradas de esquerda. Combateu a instauração do regime parlamentarista, posicionou-se à favor das reformas de base, porém, ao discordar das mudanças ministeriais ou de postos importantes no governo de João Goulart, o criticava. $O$ IBAD foi pauta de vários artigos, principalmente durante a instalação da CPI. A jornalista defendeu a elegibilidade dos cabos e soldados, seu direito ao voto, assim como aos analfabetos.

Neste sentido, alinhada ao "bloco nacional-reformista" Adalgisa se opunha e denunciava a forte campanha ideológica e multifacetada implementada com sucesso pela "elite orgânica empresarial”, cuja ação, referenciada por Dreifuss (1981, p. 230): “[...] deve ser 
considerada como a praxe de um bloco burguês de poder, premeditada e cuidadosamente amadurecida durante anos."

Assim, no contexto de intensa definição do campo político anterior ao golpe civilmilitar de 1964, suas posições e propostas, atreladas principalmente à defesa dos interesses do Brasil e ao getulismo, tiveram identidade com as forças de esquerda. Para tanto, o esquerdismo de Adalgisa Nery deve ser considerado numa perspectiva ampliada, num viés de análise conjuntural. Após o golpe civil-militar de 1964, como deputada estadual, ela procurou manifestar-se contrariamente ao regime instituído, ainda que seus discursos no plenário da ALEG fossem raros. Ela enfrentou ameaças constantes de cassação dos direitos políticos, que a atingiram, terminantemente, em outubro de 1969.

Sua mudança partidária do PSB para o PTB em 1963 evidenciou aliança mais estreita com o governo Goulart, assim como foi a cogitação de seu nome para ocupar a pasta do Ministério da Educação no início de 1964. O movimento de abril foi golpe definitivo na carreira jornalística de Adalgisa Nery.

\section{Referências}

ABREU, Alzira Alves de. Instituto Superior de Estudos Brasileiros. In: Dicionário histórico-biográfico brasileiro, pós-1930 (DHBB). Rio de Janeiro: CPDOC/FGV, 2000. Disponível em: <http://www.fgv.br/cpdoc/acervo/dicionarios/ verbete-tematico/instituto-superior-deestudos-brasileiros-iseb>. Acesso em: 30 jun. 2017.

ASSIS, Denise. Propaganda e Cinema a serviço do golpe-1962/1964. Rio de Janeiro: Mauad/FAPERJ, 2001.

BUITONI, Dulcilia Helena Schorceder. Mulher de papel: a representação da mulher na imprensa feminina brasileira. São Paulo: Loyola, 1981.

CAMPOS, Fátima Cristina Gonçalves. Visões e Vozes: o governo Goulart nas páginas da Tribuna da Imprensa e Última Hora (1961-1964) Dissertação (Mestrado em História Social das Idéias) - UFF, Niterói, 1996.

DREIFUSS, R. A. 1964: A conquista do Estado: ação política, poder e golpe de classe. Petrópolis: Ed. Vozes, 1981. 
FERREIRA, Jorge. O imaginário trabalhista: getulismo, PTB e cultura política popular 19451964. Rio de Janeiro: Civilização Brasileira, 2005.

FERREIRA, Marieta de Moraes. A reforma do jornal do Brasil. In: ABREU. Alzira Alves (Org.). A imprensa em transição: o jornalismo brasileiro nos anos 50. Rio de Janeiro: Editora FGV, 1996. p.141-155.

GRAMSCI, Antonio. Os intelectuais e a organização da cultura. Rio de Janeiro: Civilização Brasileira, 1982.

KIERNAN, V. G. Estados Unidos: o novo imperialismo. Rio de Janeiro: Record, 2009.

LABAKI, Amir. A crise da renúncia e a solução parlamentarista. São Paulo: Brasiliense, 1986.

LAMARÃO, Sérgio. Ação Democrática Parlamentar. In: ABREU, Alzira Alves. Dicionário histórico-biográfico brasileiro, pós-1930 (DHBB). Rio de Janeiro: CPDOC/FGV, 2000. Disponível em: <http://www.fgv.br/cpdoc/acervo/dicionarios/ verbete-tematico/acao-democraticaparlamentar-adp >. Acesso em: 30 jun. 2017.

MARTINS FILHO, João Roberto. Forças Armadas e política, 1945-1964: a ante sala do golpe. In: FERREIRA, Jorge; DELGADO, Lucila de Almeida Neves (Org.). O tempo da experiência democrática: da democratização de 1945 ao golpe civil-militar de 1964. Rio de Janeiro: Civilização Brasileira, 2003.

MAYER, Jorge Miguel. XAVIER, Libânia. Quadros, Jânio. In: ABREU, Alzira Alves de. Dicionário histórico-biográfico brasileiro, pós-1930 (DHBB). Rio de Janeiro: CPDOC/FGV, 2000. Disponível em: <http://www.fgv.br/cpdoc/acervo/dicionarios/ verbete-biografico/janio-dasilva-quadros >. Acesso em: 3 jun. 2017.

MORAIS, Fernando. Chatô: o rei do Brasil. São Paulo: Companhia das letras, 1994.

MOTTA, Marly Silva da. Saudades da Guanabara: o campo político da cidade do Rio de Janeiro (1960-1975). Rio de Janeiro: Ed. FGV, 2000.

ROMANO, Luís Antonio Contatori. A passagem de Sartre e Simone de Beauvoir pelo Brasil em 1960. São Paulo: Mercado das Letras, 2002.

SÁ MOTTA, Rodrigo Patto. João Goulart e a mobilização anticomunista de 1961-64. In: FERREIRA, Marieta de Moraes (Org.). João Goulart: entre a memória e a História. Rio de Janeiro: Ed. FGV, 2006.

SODRÉ, Nelson Werneck. História militar do Brasil. Rio de Janeiro: Civilização brasileira, 1965.

TOLEDO, Caio de Navarro. ISEB: fábrica de ideologias. São Paulo: Ática, 1977. 


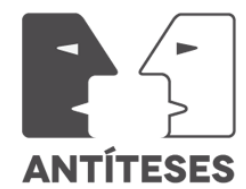

WAINER, Samuel. Minha razão de viver: memórias de um repórter. Rio de Janeiro: Record, 1988.

Recebido em 09/12/2016

Aprovado em 29/06/2107 